This Accepted Author Manuscript is copyrighted and published by Elsevier. It is posted here by agreement between Elsevier and University of Brasilia. Changes resulting from the publishing process - such as editing, corrections, structural formatting, and other quality control mechanisms - may not be reflected in this version of the text. The definitive version of the text was subsequently published in [Journal of Magnetism and Magnetic Materials, Volumes 272276, Part 3, May 2004, Pages 2400-2401, doi:10.1016/j.jmmm.2003.12.998].You may download, copy and otherwise use the AAM for non-commercial purposes provided that your license is limited by the following restrictions:

(1) You may use this AAM for non-commercial purposes only under the terms of the CC-BY-NCND license.

(2) The integrity of the work and identification of the author, copyright owner, and publisher must be preserved in any copy.

(3) You must attribute this AAM in the following format: [agreed attribution language, including link to CC BY-NC-ND license + Digital Object Identifier link to the published journal article on Elsevier's ScienceDirect ${ }^{\circledR}$ platform].

Este Manuscrito do Autor Aceito para Publicação (AAM) é protegido por direitos autorais e publicado pela Elsevier. Ele esta disponível neste Repositório, por acordo entre a Elsevier e a Universidade de Brasília. As alterações decorrentes do processo de publicação - como a edição, correção, formatação estrutural, e outros mecanismos de controle de qualidade - não estão refletidas nesta versão do texto. A versão definitiva do texto foi posteriormente publicado em [Journal of Magnetism and Magnetic Materials, Volumes 272-276, Parte 3, Maio de 2004, Paginas 2400-2401, doi:10.1016/j.jmmm.2003.12.998]. Você pode baixar, copiar e utilizar de outra forma o AAM para fins não comerciais, desde que sua licença seja limitada pelas seguintes restrições:

(1) Você pode usar este AAM para fins não comerciais apenas sob os termos da licença CC- BYNC-ND.

(2) A integridade do trabalho e identificação do autor, detentor dos direitos autorais e editor deve ser preservado em qualquer cópia.

(3) Tem de atribuir este AAM no seguinte formato: [acordo na linguagem atribuída, incluindo o link para CC BY-NC-ND licença Digital + DOI do artigo publicado na revista Elsevier ScienceDirect ${ }^{\circledR}$ da plataforma]. 


\title{
Magnetic resonance investigation of magnetic-labeled baker's yeast cells
}

J.P.M. Godoy Morais

R.B. Azevedo

L.P. Silva

Z.G.M. Lacava

S.N. Báo

O. Silva

F. Pelegrini

C. Gansau

N. Buske

I. Safarik

M. Safarikova

P.C. Moraise

\begin{abstract}
In this study, the interaction of DMSA-coated magnetite nanoparticles (5 and $10 \mathrm{~nm}$ core-size) with Saccharomyces cerevisae was investigated using magnetic resonance (MR) and transmission electron microscopy (TEM). The TEM micrographs revealed magnetite nanoparticles attached externally to the cell wall. The MR data support the strong interaction among the nanoparticles supported by the cells. A remarkable shift in the resonance field was used as signature of particle attachment to the cell wall.
\end{abstract}

PACS

75.50.Mm; 76.50+g; 87.68.+z

Keywords: Magnetic fluid; Magnetic resonance; Transmission electron microscopy; Yeast cell

The use of nanosized magnetic materials in the development of field-gradient magnetic separation (FGMS) technologies has attracted much attention in recent years. Wastewater containing processed textile dyes, for instance, is an increasing source of environmental contamination. Recent experiments showed that the yeast cells (Saccharomyces cerevisiae) efficiently interact with magnetic nanoparticles dispersed as magnetic fluids (MFs), leading to the formation of magnetic-labeled cells which could be easily separated from the system using appropriated magnetic separators [1]. Also, yeast cells are good candidates to promote removal and degradation of dyes from wastewater [2]. In this study, transmission electron microscopy (TEM) and magnetic resonance (MR) were used to investigate the interaction of $\mathrm{S}$. cerevisiae cells with magnetic nanoparticles (MNPs) after incubation with magnetite-based, DMSA-coated MF samples (DMSA-MF).

Baker's yeast (S. cerevisiae) was obtained locally. Magnetite-based (5 and $10 \mathrm{~nm}$ average diameter), DMSA-coated biocompatible MF samples were prepared as described in the literature [3]. Compressed baker's yeast $(2 \mathrm{~g})$ was suspended in saline $(6 \mathrm{~mL})$, centrifuged 
and resuspended in $6 \mathrm{~mL} 0.1 \mathrm{M} \mathrm{PBS}(\mathrm{pH}$ 7.4). After centrifugation the pellet was once again resuspended in PBS to obtain a 33\% yeast suspension ( $\mathrm{v} / \mathrm{v}$; yeast cells volume determined after sedimentation for $24 \mathrm{~h}$ at $1 \mathrm{~g}$ ). Three $\mathrm{mL}$ of the yeast suspension was added to $1 \mathrm{~mL}$ of the DMSA-MF sample containing $1.2 \times 1016$ particle/cm3. Two distinct DMSA-MF samples (5 and 10 $\mathrm{nm}$ average diameter MNP's) were used in the experiments. The suspension was mixed and then incubated at room temperature for $1 \mathrm{~h}$ without mixing. After this time period most of the yeast cells were magnetically modified by the added DMSA-MF (the cells responded to external magnetic field gradients). Nonmagnetic yeast cells and residual MF were removed by repeated static magnetic separation using PBS and saline as washing liquids. After treatment cells were harvested, fixed, and processed for TEM analysis. Modified cells were also used for MR measurments. The TEM analysis (see Fig. 1) revealed that the $5 \mathrm{~nm}$-size, DMSA-coated magnetite nanoparticles, was externally attached to the S. cerevisiae cell wall. Similar result was observed using the $10 \mathrm{~nm}$-size, magnetite-based DMSA-MF sample. Incubation for $4 \mathrm{~h}$ instead of $1 \mathrm{~h}$ leads to similar observations.

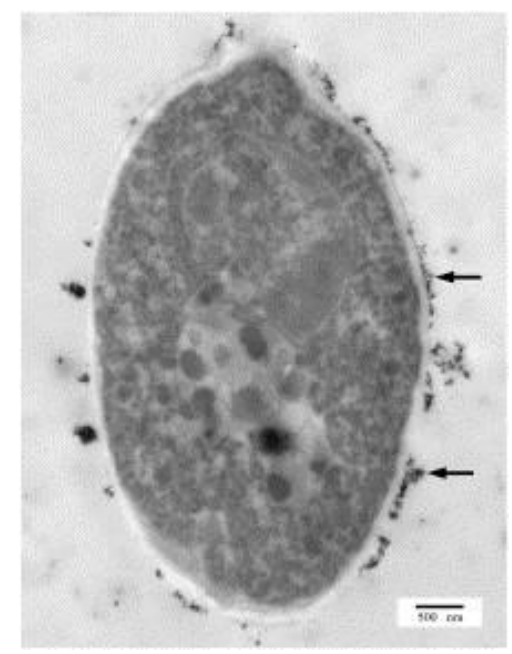

Fig. 1. TEM picture of S. cerevisiae incubated with $5 \mathrm{~nm}$ DMSA-MF. Observe MNP's attached to the cell wall (arrows). No particles were found inside the cell.

MR experiments have been successfully used to investigate biodistribution of MNPs introduced in living beings [4]. Fig. 2 shows the MR spectra of the two modified cells (open circles for the $5 \mathrm{~nm}$ and full circles for the $10 \mathrm{~nm}$ MNPs) plus the spectra of two $10 \mathrm{~nm}$-size (dashed and solid lines), magnetite-based DMSA-MF samples containing 4.8×1016 (1:1) and 4.8×1013 particle/cm3 (1:1000). The huge dilution (from 1:1 to 1:1000) of the $10 \mathrm{~nm}$-size MF sample causes a relative shift in the resonance field of about $73 \mathrm{G}$. However, the shift observed in the resonance field between the concentrated $10 \mathrm{~nm}$-size MF sample (1:1) and the modified cells using the $10 \mathrm{~nm}$-size, magnetite-based DMSA-MF sample, was about $250 \mathrm{G}$. This remarkable resonance field shift is the signature of a strong interaction among the MNP's 
when attached to the S. cerevisiae cell wall. The MR spectrum of the modified cells using the 5 nm-core, magnetite-based DMSA-MF sample, is also shown in Fig. 2 (open circles).

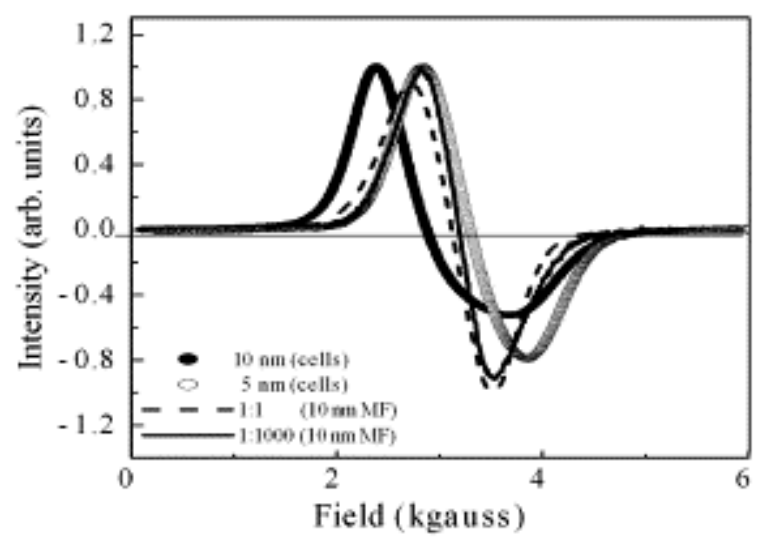

Fig. 2. Magnetic resonance spectra of the 5 (open circles) and $10 \mathrm{~nm}$ (full circles) nanoparticles in labeled cells. Solid and dashed lines represent the spectra of the $10 \mathrm{~nm}$ magnetite suspended as a stable magnetic fluid samples at different concentrations (see text).

In conclusion, 5 and $10 \mathrm{~nm}$-sized magnetite particles, DMSA-coated, do attach to the $\mathrm{S}$. cerevisiae cell wall after incubation of the yeast cells with the corresponding biocompatible magnetic fluid samples. Magnetic resonance data confirm that both nanoparticles are firmly attached to the cells as revealed by the TEM micrographs.

The authors acknowledge the financial support of the Brazilian agencies CNPq and FINATEC.

\section{References}

[1] I. Safarik, L. Ptackova, M. Safarikova, Eur. Cells Mater. 3 (S2) (2002) 52.

[2] M.A.M. Martins, M.H. Cardoso, M.J. Queiroz, M.T. Ramalho, A.M.O. Campos, Chemosphere 38 (1999) 2455.

[3] T. Goetze, C. Gansau, N. Buske, M. Roeder, P. Gornert, .M. Bahr, J. Magn. Magn. Mater. 252 (2002) 399.

[4] L.M. Lacava, Z.G.M. Lacava, M.F. Da Silva, O. Silva, S.B. Chaves, R.B. Azevedo, F. Pelegrini, C. Gansau, N. Buske, D. Sabolovic, P.C. Morais, Biophys. J. 80 (2001) 2483. 